\title{
Chemical variables influencing microbial properties in composted tannery sludge-treated soil
}

\author{
A. S. F. Araújo ${ }^{1}$ - V. M. Santos ${ }^{1}$ - A. R. L. Miranda ${ }^{1}$ L. A. P. L. Nunes ${ }^{1}$ • \\ C. T. S. Dias ${ }^{2}$ W. J. de Melo ${ }^{3}$
}

Received: 28 February 2017/Revised: 5 May 2017/Accepted: 11 September 2017/Published online: 18 September 2017

(C) Islamic Azad University (IAU) 2017

\begin{abstract}
Repeated applications of composted tannery sludge to arable soils have the potential to greatly alter soil chemistry and thus potentially influence the soil microbial community over time. This study performed multivariate analyses using the data of soil microbial biomass, respiration, and enzymes activities obtained during 5 years (2010-2014) in a long-term experiment with composted tannery sludge amendment. The correlation between the soil microbial and chemical properties, via the analysis of similarity matrices, revealed calcium as the main single factor influencing the microbial properties, in 2010 and 2011. Afterward, chromium was the most important chemical variables driving the microbial properties in 2012, 2013, and 2014. The non-metric multidimensional scaling demonstrated that the soil microbial properties changed with composted tannery sludge application from 2010 to 2014. Multivariate analysis from soil microbial
\end{abstract}

Editorial responsibility: Binbin Huang

A. S. F. Araújo

asfaruaj@yahoo.com.br

1 Soil Quality Lab, Agricultural Science Center, Federal University of Piauí, Teresina, PI 64049-55, Brazil

2 Department of Statistic, ESALQ, University of São Paulo, Piracicaba, SP, Brazil

3 São Paulo State University, Jaboticabal., Brasil University, Descalvado, SP, Brazil data with composted tannery sludge amendment, during 5 years, showed calcium and chromium as being the most significant variables influencing the soil microbial properties in composted tannery sludge-treated soil.

Keywords Wastes $\cdot$ Microbial properties $\cdot$ Microbial activity $\cdot$ Soil biochemistry

\section{Introduction}

Tannery sludge (TS), which is generated during the process of leather tanning, consists of a high amounts of organic matter, chromium $(\mathrm{Cr})$, salts, and carbonates (Santos et al. 2011). Proposed uses of tannery sludge include use as a soil nutrient additive owing to its high organic content (Singh and Agrawal 2008). However, there remain concerns regarding high concentrations of $\mathrm{Cr}$, carbonates, and salts that have the potential to adversely affect soil quality and chemistry (Patel and Patra 2014).

Soil processes are mediated by microbial properties which act on organic matter decomposition and nutrient cycling (Kennedy and Smith 1995). Also, the microbial communities respond quickly to environmental changes caused by waste amendments (Kelly et al. 2011; Santos et al. 2011; Singh et al. 2011). Thus, soil microbial properties can serve as suitable indicators of anthropogenic disturbances, such as TS (Nakatani et al. 2011) and sewage sludge amendment (Singh et al. 2011).

Recently, composting has been recognized as an alternative method to TS detoxification before soil application (Santos et al. 2011; Silva et al. 2014). In addition, the process of composting converts, by microbial action, plant nutrients present in the waste into soluble forms, available to plants (Ndegwa and Thompson 2001). Therefore, studies 
focusing on TS composting were performed aiming to evaluate the amendment of composted tannery sludge (CTS) on soil microbial properties in long term (Santos et al. 2011; Gonçalves et al. 2014; Silva et al. 2014; Araújo et al. 2015). These studies have shown that the annual application of CTS changed the soil microbial biomass, respiration, and enzymes activity (Santos et al. 2011; Gonçalves et al. 2014; Silva et al. 2014; Araújo et al. 2015), and increased the soil organic $\mathrm{C}, \mathrm{pH}$, salinity, and Cr content (Araújo et al. 2013; Araújo et al. 2016). Similarly, Singh and Agrawal (2010) reported that the amendment of sewage sludge also increased the values of soil organic $\mathrm{C}, \mathrm{pH}$, electric conductivity, and metals in soil.

Although CTS amendment has the potential to alter soil microbial characteristics, it is unknown the pattern of microbial responses in long term, and how the chemistry of the CTS materials could be influencing soil microbial characteristics over time. Therefore, multivariate analysis has been strongly indicated to evaluate changes or patterns in soil microbial properties due to treatment and time effects (Spedding et al. 2004). The analysis of similarity (ANOSIM) has been used to evaluate a dissimilarity matrix rather than raw data and aligns to the non-metric multidimensional scaling (NMDS) procedure (Clarke 1993). On the other hand, BIOENV analysis allows the exploration of environmental variables that best correlate to biological properties and defines an optimal subset of environmental variables which explains the biotic structure (Clarke and Warwick 1994). These tests are complementary approaches in evaluating nonparametric multivariate data. In this way, this study analyzed, through multivariate analyses (NMDS, ANOSIM, and BIOENV), the data of soil microbial properties obtained during 5 years (2010-2014) in a long-term experiment with CTS amendment. The experiments were performed, during 2010-2014, at the Long-Term Experimental Field of the Agricultural Science Center, located at the city of Teresina, Piauí, Brazil.

\section{Materials and methods}

The experiments were performed at the Long-Term Experimental Field of the Agricultural Science Center, Teresina, Piauí, Brazil $\left(05^{\circ} 05 \mathrm{~S} ; 42^{\circ} 48^{\prime} \mathrm{W}, 75 \mathrm{~m}\right)$. The regional climate is tropical and dry (Köppen) characterized by two distinct seasons: (1) a rainy summer and (2) a dry winter, with average annual temperatures of $30{ }^{\circ} \mathrm{C}$ and rainfall of $1200 \mathrm{~mm}$. The rainy season extends from January to April, during which $90 \%$ of the total annual rainfall occurs. The soil is classified as a Fluvisol with the following granulometric fractions at 0-20-cm depth: $10 \%$ clay, $28 \%$ silt, and $62 \%$ sand.

CTS used during 2010-2014 was produced by mixing TS with sugarcane straw and cattle manure (ratio 1:3:1; v:v:v) during 85 days. The main characteristics of CTS during 2010-2014 are described in Table 1 (Araújo et al. 2015). CTS was applied during 2010-2014 in five rates: 0 (without CTS application), 2.5, 5, 10, and $20 \mathrm{t} \mathrm{ha}^{-1}$ of CTS (dry basis). The experimental site was arranged in a completely random design with four replicates. For additional details of the experiment, in each year, see Gonçalves et al. (2014), Silva et al. (2014), and Araújo et al. (2015).

The soil microbial and chemical properties $(0-20 \mathrm{~cm}$ depth, 60 days after CTS amendment in each year) evaluated in the experiments, from 2010 to 2014, were: microbial biomass $\mathrm{C}(\mathrm{MBC})$ and $\mathrm{N}(\mathrm{MBN}), \mathrm{MBC} / \mathrm{MBN}$ ratio, substrate-induced respiration (SIR), basal respiration (BR), respiratory quotient $\left(\mathrm{qCO}_{2}\right)$, fluorescein diacetate hydrolysis (FDA), and dehydrogenase activity (DHA) (Alef and Nannipieri 1995); soil pH, electric conductivity (EC), phosphorus (P), potassium (K), calcium (Ca), and magnesium (Mg) (Tedesco et al. 1995), total organic C (TOC) (Yeomans and Bremner 1998), and total Cr concentration (USEPA 1996). The detailed methods used in these experiments can be found in Araújo et al. (2015).

The data derived from these experiments were tested for normality prior to multivariate analysis. We used a nonmetric multidimensional scaling (NMDS) analysis of the coefficient of similarity of Bray-Curtis. Analysis of similarity (ANOSIM) was used to test for significant differences between treatments (CTS rates). An ANOSIM R statistic was generated based on comparison of rank similarity within and among groups of samples, and significance of the group dissimilarity was based on permutation tests. An $R$ value of 1 indicates complete dissimilarity among groups, and $R=0$ indicates a high degree of similarity. The relationships between the microbial and chemical properties of the soil were evaluated by the analysis of similarity matrices (BIOENV) (Clarke and Warwick 1994). This analysis selects chemical variables which best explain the response of soil microbial properties after CTS amendment, by maximizing the correlation between their respective similarity matrices with the application of a weighted Spearman's correlation coefficient (Clarke and Warwick 1994). All analyses of NMDS, ANOSIM and BIOENV procedure were performed using the Primer 6.0 (Clarke and Gorley 2006). 
Table 1 Chemical composition of CTS

Fig. 1 Soil microbial properties as affected by CTS rates and years. Effects of CTS amendment on soil microbial biomass $\mathrm{C}$ (MBC; $\mathrm{mg} \mathrm{C} \mathrm{kg}^{-1}$ ), soil microbial biomass $\mathrm{N}$ (MBN; mg N kg-1), microbial $\mathrm{C}$ : microbial $\mathrm{N}$ stoichiometry (MBC MBN), and substrateinduced respiration (SIR; $\left.\mathrm{mg} \mathrm{C} \mathrm{kg}{ }^{-1}\right)$ during 5 years $(1$, $2,3,4$, and 5)

Fig. 2 Soil microbial properties as affected by CTS rates and years. Effects of CTS amendment on basal respiration (BR; mg CO $2-\mathrm{C} \mathrm{kg}^{-1} \mathrm{~d}^{-1}$ ), microbial respiratory quotient $\left(\mathrm{qCO}_{2} ; \mathrm{g} \mathrm{CO}_{2}-\mathrm{C} \mathrm{d}^{-1} \mathrm{~g}^{-1}\right.$ MBC), dehydrogenase (DHA; $\mu \mathrm{g}$ triphenyltetrazolium chloride $\mathrm{g}^{-1}$ ), and fluorescein diacetate hydrolysis (FDA; $\mu \mathrm{g} \mathrm{FDA} \mathrm{g}^{-1}$ ) during 5 years $(1,2,3,4$, and 5$)$

\begin{tabular}{|c|c|c|c|c|c|c|c|c|c|c|c|c|c|}
\hline $\begin{array}{l}\mathrm{pH} \\
\mathrm{H}_{2} \mathrm{O}\end{array}$ & $\begin{array}{l}\text { TOC } \\
\left(\mathrm{g} \mathrm{kg}^{-1}\right)\end{array}$ & $\mathrm{N}$ & $\mathrm{P}$ & $\mathrm{K}$ & $\mathrm{Ca}$ & $\mathrm{Mg}$ & $\mathrm{Na}$ & $\mathrm{S}$ & $\begin{array}{l}\mathrm{Cu} \\
(\mathrm{mg}\end{array}$ & $\begin{array}{r}\mathrm{Ni} \\
\left.\mathrm{g}^{-1}\right)\end{array}$ & $\mathrm{Cd}$ & $\mathrm{Cr}$ & $\mathrm{Pb}$ \\
\hline 7.5 & 201 & 15 & 4.9 & 2.9 & 121 & 7.2 & 49.1 & 10 & 16 & 23 & 1.9 & 1943 & 40 \\
\hline MLP* & - & - & - & - & - & - & - & - & 200 & 70 & 3 & 150 & 180 \\
\hline
\end{tabular}

* Maximum limit permitted by Brazilian regulation. TOC total organic $\mathrm{C}$
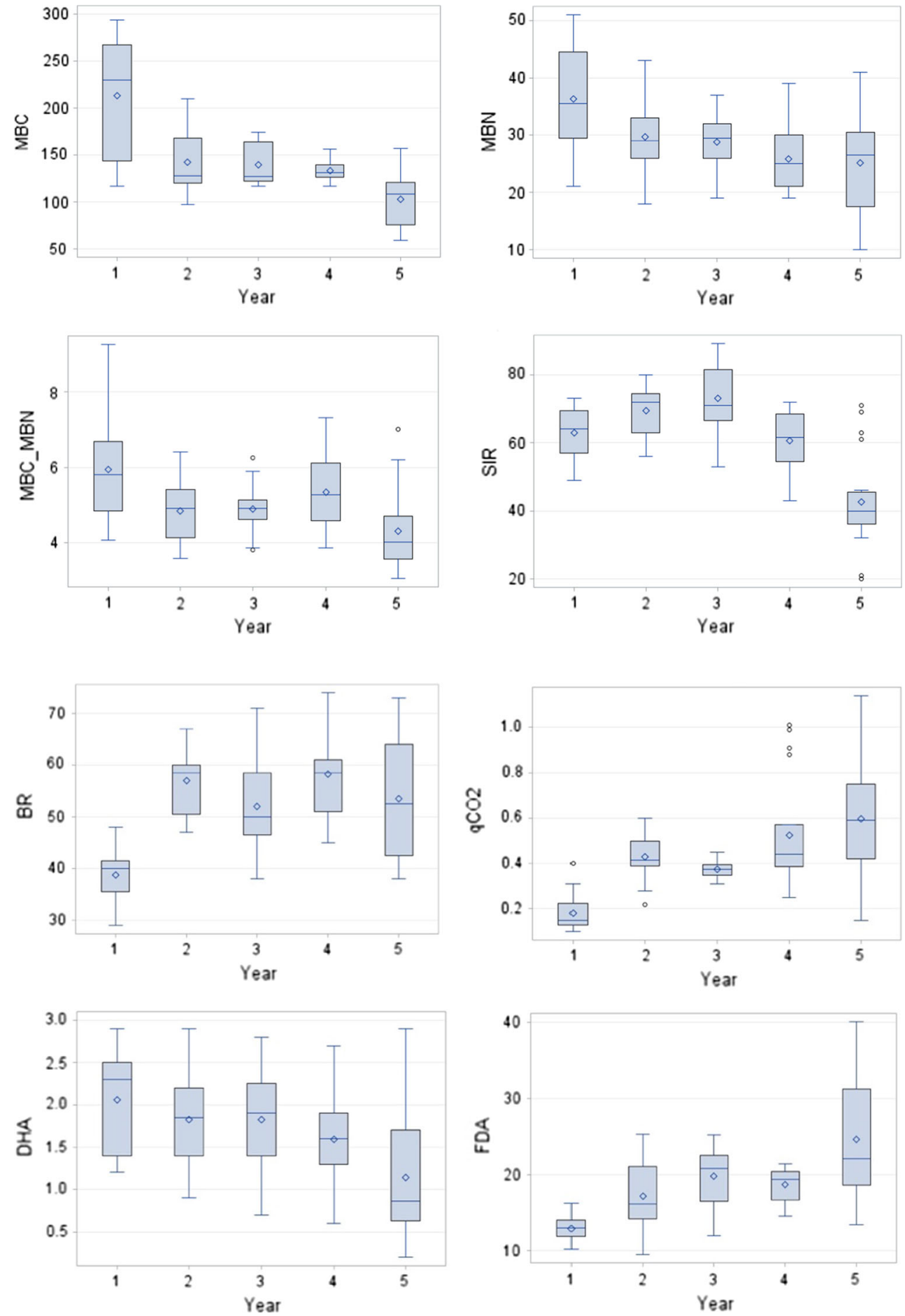


\section{Results and discussion}

The soil microbial properties exhibited differential responses with CTS amendment over 5 years (Figs. 1, 2). From 2010 to 2014, the MBC, MBN, and MBC/TOC ratio decreased in all treatments with CTS as compared with unamended soil (Fig. 1). The substrate-induced respiration (SIR) increased with $5 \mathrm{Mg} \mathrm{ha}^{-1}$ and decreased with $20 \mathrm{Mg} \mathrm{ha}^{-1}$ (Fig. 1). The basal respiration (BR) and $\mathrm{qCO}_{2}$ increased with CTS amendment as compared with unamended soil (Fig. 2). DHA activity did not change for the treatments of $0-10 \mathrm{Mg} \mathrm{ha}^{-1}$, but decreased with the amendment of $20 \mathrm{Mg} \mathrm{ha}^{-1}$. In contrast, FDA hydrolysis increased in all treatments from 2010 to 2014 (Fig. 2).

As shown in Table 2, repeated amendment of CTS changed the soil chemical properties significantly with increase in soil $\mathrm{pH}$, salinity, and $\mathrm{Cr}$ accumulation, which may be harmful to soil microbial processes (Ben Achiba et al. 2009). However, previous studies regarding the use of composted wastes (e.g., municipal solid waste and sewage sludge) have reported positive effect on microbial biomass and enzymatic activity in the long term (García-Gil et al. 2000; Bouzaiane et al. 2007; Scherer et al. 2011). On the contrary, the results found in this study indicated that microbial biomass decreased with CTS amendment across the years, and it may be related to the above-mentioned soil chemical changes.

Interestingly, soil enzymes exhibited a different pattern with CTS amendment over the 5-year time period. DHA activity was negatively influenced by CTS amendment, and it may have occurred due to the accumulation of $\mathrm{Cr}$ since this enzyme is highly sensitive to Cr contamination (Huang et al. 2009). Also, it may be associated with the reduction on microbial biomass since this enzyme exists within living cells. In contrast, FDA hydrolysis activity increased significantly with CTS amendment over time, and it can be explained by the characteristics of FDA hydrolysis: (a) FDA hydrolysis activity is not specific to SMB as other organisms (e.g., algae and protozoa) can also release this group of
Table 3 R-statistic values in pairwise comparisons of CTS using the analysis of similarities (ANOSIM)

\begin{tabular}{llllll}
\hline CTS & \multicolumn{4}{l}{ Pairwise test } \\
\cline { 2 - 6 } & 2010 & 2011 & 2012 & 2013 & 2014 \\
\hline $0,2.5$ & $0.688^{*}$ & $0.990^{*}$ & $1.000^{*}$ & $1.000^{*}$ & $1.000^{*}$ \\
0,5 & $0.979^{*}$ & $1.000^{*}$ & $1.000^{*}$ & $1.000^{*}$ & $1.000^{*}$ \\
0,10 & $1.000^{*}$ & $1.000^{*}$ & $1.000^{*}$ & $1.000^{*}$ & $1.000^{*}$ \\
0,20 & $1.000^{*}$ & $1.000^{*}$ & $1.000^{*}$ & $1.000^{*}$ & $1.000^{*}$ \\
$2.5,5$ & $0.917^{*}$ & $1.000^{*}$ & $0.125^{\text {ns }}$ & $0.865^{*}$ & $1.000^{*}$ \\
$2.5,10$ & $0.979^{*}$ & $0.760^{*}$ & $1.000^{*}$ & $1.000^{*}$ & $1.000^{*}$ \\
$2.5,20$ & $1.000^{*}$ & $1.000^{*}$ & $1.000^{*}$ & $1.000^{*}$ & $1.000^{*}$ \\
5,10 & $0.208^{\mathrm{ns}}$ & $1.000^{*}$ & $0.990^{*}$ & $1.000^{*}$ & $0.750^{*}$ \\
5,20 & $1.000^{*}$ & $1.000^{*}$ & $1.000^{*}$ & $1.000^{*}$ & $1.000^{*}$ \\
10,20 & $1.000^{*}$ & $0.885^{*}$ & $0.490^{*}$ & $1.000^{*}$ & $0.802^{*}$ \\
Global R & $0.863^{*}$ & $0.93^{*}$ & $0.846^{*}$ & $0.971^{*}$ & $0.962^{*}$ \\
\hline ANOSIM & & & & & \\
\end{tabular}

ANOSIM $R$ values closer to 1 indicate community dissimilarity. Pairwise tests where ANOSIM $R$ values were greater than 0.4 were considered significantly different groups and nonrandom at $p<0.05$ ns non-significant

enzymes (Pereira et al. 2004); and (b) as a group of enzymes (Taylor et al. 2002), FDA hydrolysis represents an exocellular activity and can be found bound to soil colloid and organic matter (Swisher and Carroll 1980). It means that FDA presents higher resistance in soil due to the protective effect of organic matter on the formation of organic enzyme complexes (Chaer et al. 2009).

The ANOSIM for the soil microbial properties showed that all treatments were significantly different (Table 3), indicating that each CTS rate resulted in a differential effect on soil microbial properties. The $R$ values varied between the pairwise treatments over time (Table 3). In the first year, the treatments without CTS application $\left(0 \mathrm{t} \mathrm{ha}^{-1}\right)$ and with $2.5 \mathrm{tha}^{-1}$ CTS showed low dissimilarity with $R$ values lower than 1, while that the comparison between 0 and $20 \mathrm{tha}^{-1}$ (highest CTS rate) showed a high dissimilarity. These results suggest that, initially, the lowest CTS rate did not influence greatly the soil microbial
Table 2 Changes in soil $\mathrm{pH}$, electrical conductivity (EC), total organic C (TOC), and total Cr content after 5 years of CTS amendment

\begin{tabular}{lllllllll}
\hline & $\begin{array}{l}\mathrm{Cr} \\
\left(\mathrm{mg} \mathrm{kg}^{-1}\right)\end{array}$ & $\begin{array}{l}\mathrm{pH} \\
\left(\mathrm{CaCl}_{2}\right)\end{array}$ & $\begin{array}{l}\mathrm{CE} \\
\left(\mathrm{dSm}^{-1}\right)\end{array}$ & $\begin{array}{l}\mathrm{TOC} \\
\left(\mathrm{g} \mathrm{kg}^{-1}\right)\end{array}$ & $\begin{array}{l}\mathrm{Ca} \\
\left(\mathrm{cmol}_{\mathrm{c}} \mathrm{dm}^{-3}\right)\end{array}$ & $\mathrm{Mg}$ & $\mathrm{Na}$ \\
\hline 0 & $4.42 \mathrm{e}$ & $6.5 \mathrm{~b}$ & $0.67 \mathrm{~b}$ & $5.5 \mathrm{~b}$ & $1.36 \mathrm{c}$ & $2.21 \mathrm{a}$ & $0.75 \mathrm{a}$ & $4.1 \mathrm{c}$ \\
2.5 & $29.38 \mathrm{~d}$ & $6.7 \mathrm{~b}$ & $0.71 \mathrm{~b}$ & $7.0 \mathrm{a}$ & $2.02 \mathrm{bc}$ & $2.25 \mathrm{a}$ & $0.78 \mathrm{a}$ & $5.0 \mathrm{~b}$ \\
5 & $50.83 \mathrm{c}$ & $6.9 \mathrm{~b}$ & $0.78 \mathrm{~b}$ & $7.3 \mathrm{a}$ & $2.61 \mathrm{a}$ & $2.31 \mathrm{a}$ & $0.80 \mathrm{a}$ & $5.9 \mathrm{a}$ \\
10 & $102.26 \mathrm{~b}$ & $7.5 \mathrm{a}$ & $0.79 \mathrm{~b}$ & $7.7 \mathrm{a}$ & $2.43 \mathrm{ab}$ & $2.28 \mathrm{a}$ & $0.85 \mathrm{a}$ & $5.8 \mathrm{a}$ \\
20 & $150.15 \mathrm{a}$ & $7.8 \mathrm{a}$ & $0.91 \mathrm{a}$ & $8.5 \mathrm{a}$ & $2.73 \mathrm{a}$ & $2.23 \mathrm{a}$ & $0.88 \mathrm{a}$ & $6.1 \mathrm{a}$ \\
\hline
\end{tabular}

TOC total organic C. Values followed by the same letter within each column are not significantly different at $5 \%$ level, as determined by Student's $t$ test 
biomass, respiration, and enzymes activity. On the other hand, the results showed that, in the last 3 years, the application of CTS has changed the content of microbial biomass, respiration rates, and enzymes activity. The global $R$ values increased from 0.863 to 0.962 at 2010 and 2014, and it indicates an increase in the dissimilarity between the treatments. It means that, over time, the treatments were different between them and, more importantly, the application of CTS changed adversely the soil microbial properties. These changes in microbial biomass, respiration, and enzymes can be associated with the changes in the soil chemical properties after CTS application. As shown in Table 1, CTS presents high alkalinity and organic $\mathrm{C}, \mathrm{Ca}, \mathrm{Na}$, and $\mathrm{Cr}$ content. Therefore, application of CTS increased, over time, the content of these elements in the soil.

In fact, the correlation between the soil microbial variables and chemical properties, via BIOENV, revealed $\mathrm{TOC}, \mathrm{Cr}, \mathrm{Ca}, \mathrm{EC}$, and $\mathrm{pH}$ as the main variables influencing the soil microbial properties. Initially, TOC, $\mathrm{Cr}$, and $\mathrm{Ca}$ influenced the microbial properties (Table 4). However, Ca (correlation coefficient of 0.733 and 0.793 , in 2010 and 2011, respectively) showed to be the most important single factor influencing the microbial properties. At the 2012, 2013, and 2014, TOC, Cr, EC, and $\mathrm{pH}$ were the combined variables controlling the microbial properties. However, in these last 3 years $\mathrm{Cr}$ (correlation coefficient of $0.824,0.704$, and 0.722 in 2012, 2013, and 2014, respectively) was the most important chemical variables driving the microbial properties (Table 4).

According to the analysis of similarity matrices BIOENV, Ca was the single variable that initially influenced the microbial properties in the soils amended with CTS. In this long-term experiment, the results showed an increase in $\mathrm{Ca}$ content in soil after CTS amendment (Araújo et al. 2016) and it influenced negatively the soil microbial biomass due to the lower bioavailability of organic matter to soil microbial processes promoted by the high Ca content (Rosenberg et al. 2003). Therefore, Ca acts indirectly on soil microorganisms inhibiting their access to the bioavailable fraction of the organic matter via chemical binding with its labile structures (Whittinghill and Hobbie
2012). These results are in agreement with Aoyama et al. (2006), who reported that $\mathrm{Ca}$ was the major factor affecting soil microbial properties with composted lime-treated sewage sludge.

$\mathrm{Cr}$ was also the single variable that significantly influenced the soil microbial biomass because of its strong accumulation from 2010 to 2014 (Araújo et al. 2016). It indicates that the application of CTS increased $\mathrm{Cr}$ bioavailability and adversely affected the soil microbial biomass, respiration, and enzymes activity. According to Ackerley et al. (2006), Cr compounds are strong oxidizing agents and permeate the microbial cellular membranes through surface anionic transport systems, so resulting in extensive cellular oxidative stress and DNA damage. These results are in contrast with those of Nakatani et al. (2011), who evaluated TS amendment over 2 years and did not find a negative effect on the soil microbial community with a concentration of $27 \mathrm{mg} \mathrm{kg}^{-1} \mathrm{Cr}$ in the soil. However, the $\mathrm{Cr}$ content found in our study $\left(59.5 \mathrm{mg} \mathrm{kg}^{-1}\right.$ with $10 \mathrm{Mg} \mathrm{ha}^{-1} \mathrm{CTS}$; Araújo et al. 2016) was twice as high as that reported by Nakatani et al. (2011); thus, Cr directly affected the soil microbial properties in our experiment. Similarly, Onweremadu and Nwufo (2009) observed significant reduction of microbial biomass $(41 \%)$ and respiration (17\%) in soil with $100 \mathrm{mg} \mathrm{Cr}$ $\mathrm{kg}^{-1}$ and suggested that high concentration of $\mathrm{Cr}$ concentration in soil is inhibitory to accumulation of microbial biomass $\mathrm{C}$.

The non-metric multidimensional scaling (NMDS) demonstrated that the soil microbial properties changed with CTS application from 2010 to 2014 (Fig. 3). At the first year of CTS application, the separation of treatments was not well-defined and clustered over three main groups $(0 ; 2.5$ and $5 ; 10$ and 20$)$. From the second to the third year, there were three main groups $(0$ and $2.5 ; 5$ and $10 ; 20)$. At the fourth year, the treatments were clustered over four groups $(0 ; 2.5 ; 5$ and $10 ; 20)$, and, at the fifth year, all treatments were clearly separated and indicated that each one was comprised of different characteristics influencing the microbial properties of the soil.

The analysis of NMDS was used to find relationship between the soil microbial properties and the CTS rates
Table 4 BIOENV analysis of similarity matrices of microbial and chemicals variables

\begin{tabular}{lllll}
\hline Year & Combined variables & Correlation coefficient & Single & Correlation coefficient \\
\hline 2010 & TOC. Cr. Ca & 0.837 & $\mathrm{Ca}$ & 0.733 \\
2011 & TOC. Cr. Ca & 0.844 & $\mathrm{Ca}$ & 0.793 \\
2012 & TOC. Cr. EC & 0.911 & $\mathrm{Cr}$ & 0.824 \\
2013 & TOC. Cr. EC & 0.875 & $\mathrm{Cr}$ & 0.704 \\
2014 & Cr. pH. EC & 0.955 & $\mathrm{Cr}$ & 0.722 \\
\hline
\end{tabular}


Fig. 3 Non-metric multidimensional scaling (NMDS) analysis based on soil microbial properties during 5 years of CTS amendment. (filled circle: $0 \mathrm{Mg} \mathrm{ha}^{-1}$; $\mathrm{x}$ :

$2.5 \mathrm{Mg} \mathrm{ha}^{-1}$; filled square:

$5 \mathrm{Mg} \mathrm{ha}^{-1}$; asterisk:

$10 \mathrm{Mg} \mathrm{ha}^{-1}$; filled triangle:

$20 \mathrm{Mg} \mathrm{ha}^{-1}$ )
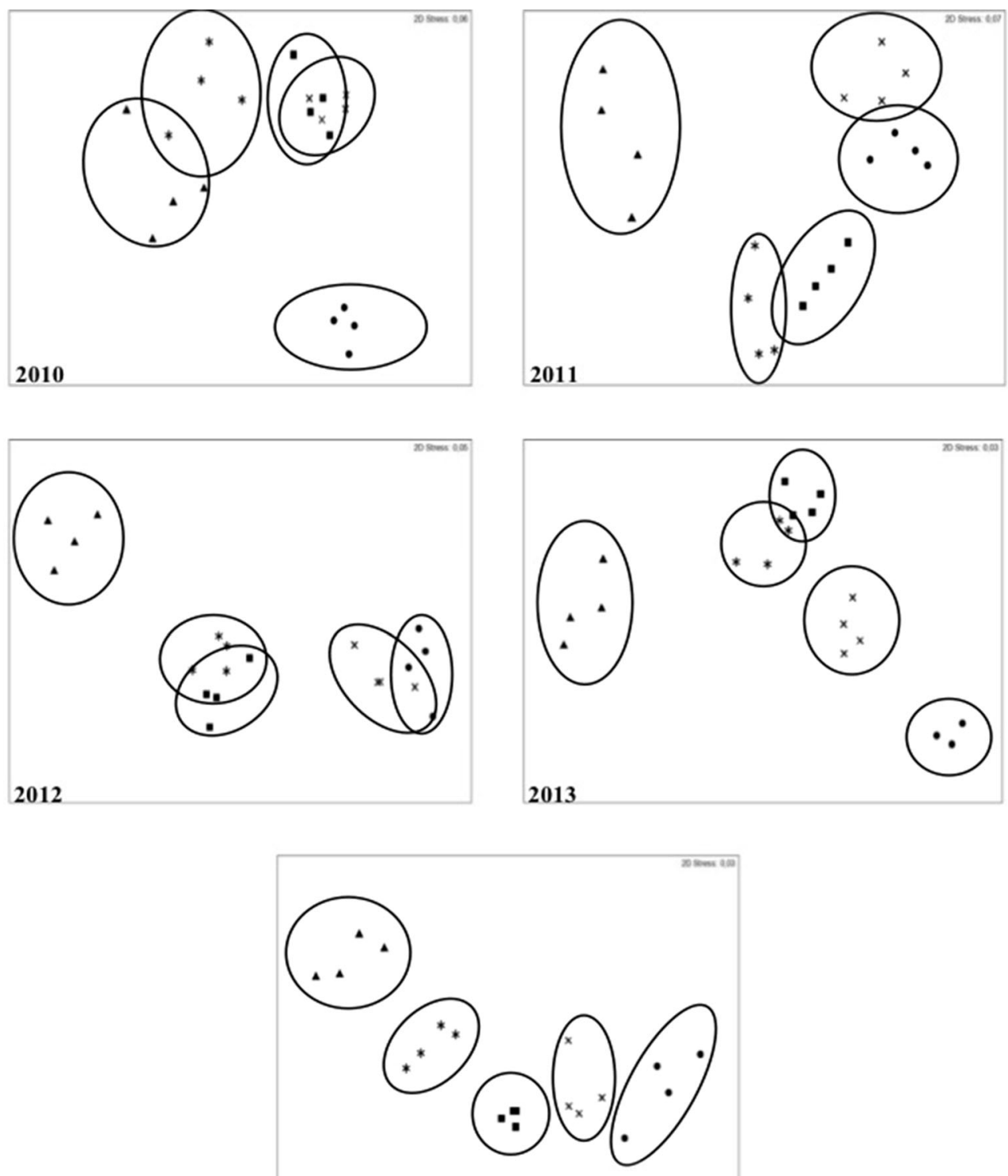

2014

over time. This method produces an ordination based on a dissimilarity matrix, i.e., it represents the pairwise dissimilarity between treatments (Clarke 1993). Thus, the results revealed that there was a clear dissimilarity between the treatments. In the initial period of CTS amendment, the dissimilarity between the rates was relatively small and consisted of three main groups with the lowest and highest CTS rates. However, in the last 2 years, the effect of CTS was more evident, separating each treatment from the others. It means that soil microbial biomass, respiration, and enzymes activity were strongly influenced by CTS rates, changing their values over time. In addition, the NMDS demonstrated that the dissimilarity in the microbial properties was more pronounced between the unamended soil and the highest CTS rates. These results suggest that the contrasting soil chemical properties promoted by different CTS rates influenced negatively the soil microbial properties over time. The consequence of changes in the microbial status after repeated applications of CTS is the inability of the soil microorganisms to properly play their functions in the environment and improve the soil quality.

\section{Conclusion}

In conclusion, multivariate analysis from soil microbial data with CTS amendment, during 5 years, showed that chemical variables influence the soil microbial properties. In this study, calcium and chromium were, specifically, the most significant variables influencing the soil 
microbial biomass, respiration, and enzymes activity in CTS-treated soil.

Acknowledgements The authors thank "Coordenação de Aperfeiçoamento de Pessoal de Nivel Superior-CAPES" (PNPD Grant 23038.007660/2011-51), and "Conselho Nacional de Desenvolvimento Científico e Tecnológico-CNPq" (Grants Universal 471347/2013-2, and Researcher Fellowship 305102/2014-1) for financial support to this project.

\section{References}

Ackerley DF, Barak Y, Lynch SV, Curtin J, Matin A (2006) Effect of chromate stress on Escherichia coli K-12. J Bacteriol 188:3371-3381

Alef K, Nannipieri P (1995) Methods in applied soil microbiology and biochemistry. Academic Press, London, p 576

Aoyama M, Zhou B, Saitoh M, Yamaguchi N (2006) Microbial biomass in soils with calcium accumulation associated with the application of composted lime-treated sewage sludge. Soil Sci Plant Nutr 52:177-185

Araújo ASF, Silva MDM, Leite LFC, Araujo FF, Dias NS (2013) Soil $\mathrm{pH}$, electric conductivity and organic matter after three years of consecutive applications of composted tannery sludge. Afr J Agric Res 8:1204-1208

Araújo ASF, Miranda ARL, Oliveira MLJ, Santos VM, Nunes LAPL, Melo WJ (2015) Soil microbial properties after 5 years of consecutive amendment with composted tannery sludge. Environ Monit Assess 187:4153-4160

Araújo ASF, Lima LM, Melo WJ, Santos VM, Araujo FF (2016) Soil properties and cowpea yield after six years of consecutive amendment of composted tannery sludge. Acta Sci Agron 38:407-413

Ben Achiba W, Gabteni N, Lakhdar A, Du Laing G, Verloo N, Jedidi N, Gallali T (2009) Effects of 5-year application of municipal solid waste compost on the distribution and mobility of heavy metals in a Tunisian calcareous soil. Agric Ecosyst Environ 130:156-163

Bouzaiane O, Cherif H, Ayari F, Jedidi N, Hassen A (2007) Municipal solid waste compost dose effects on soil microbial biomass determined by chloroform fumigation-extraction and DNA methods. Ann Microbiol 57:681-686

Chaer G, Fernandes M, Myrold D, Bottomley P (2009) Comparative resistance and resilience of soil microbial communities and enzymes activities in adjacent native forest and agricultural soils. Microb Ecol 58:414-424

Clarke KR (1993) Non-parametric multivariate analyses of changes in community structure. Austral J Ecol 18:117-143

Clarke KR, Gorley RN (2006) Primer v6: user manual/tutorial. Primer-E Ltd, Plymouth

Clarke KR, Warwick RM (1994) Changes in marine communities: an approach to statistical analysis and interpretation. Plymouth Marine Laboratory, Plymouth, p 144

García-Gil JC, Plaza C, Soler-Rovira P, Polo A (2000) Long-term effects of municipal solid waste compost application on soil enzyme activities and microbial biomass. Soil Biol Biochem 32:1907-1913
Gonçalves ICR, Araújo ASF, Nunes LAPL, Melo WJ (2014) Soil microbial biomass after two years of consecutive application. Acta Sci Agron 36:35-41

Huang S, Peng B, Yang Z, Zhou L (2009) Chromium accumulation, microorganism population and enzyme activities in soils around chromium-containing slag heap of steel alloy factory. Trans Nonferrous Metals Soc China 19:241-248

Kelly JJ, Policht K, Grancharova T, Hundal LS (2011) Distinct responses in ammonia-oxidizing archaea and bacteria after addition of biosolids to an agricultural soil. Appl Environ Microbiol 77:6551-6558

Kennedy AC, Smith KL (1995) Soil microbial diversity and the sustainability of agricultural soils. Plant Soil 170:75-86

Nakatani AS, Martines AM, Nogueira MA, Fagotti DSL, Oliveira AG, Bini D, Sousa JP, Cardoso EJBN (2011) Changes in the genetic structure of bacteria and microbial activity in an agricultural soil amended with tannery sludge. Soil Biol Biochem 43:106-114

Ndegwa PM, Thompson SA (2001) Integrating composting and vermicomposting in the treatment and bioconversion of biosolids. Bioresour Technol 76:107-112

Onweremadu EU, Nwufo MI (2009) Pedogenetic activities of soil microbes as influenced by trivalent cationic chromium. Res $\mathbf{J}$ Soil Biol 1:8-14

Patel A, Patra DD (2014) Influence of heavy metal rich tannery sludge on soil enzymes vis-à-vis growth of Tagetes minuta, an essential oil bearing crop. Chemosphere 112:323-332

Pereira SV, Martinez CR, Porto ER, Oliveira BRB, Maia LC (2004) Microbial activity in a semiarid soil cultivated with Atriplex nummularia. Pesqui Agropecu Bras 39:757-762

Rosenberg W, Nierop KGJ, Knicker H, de Jager PA, Kreutzer K, Weib T (2003) Liming effects on the chemical composition of the organic surface layer of a mature Norway spruce stand (Picea abies [L.] Karst.). Soil Biol Biochem 35:155-165

Santos JA, Nunes LAPL, Melo WJ, Araujo ASF (2011) Tannery sludge compost amendment rates on soil microbial biomass of two different soils. Eur J Soil Biol 47:146-151

Scherer HW, Metker DJ, Welp G (2011) Effect of long-term organic amendments on chemical and microbial properties of a luvisol. Plant Soil Environ 57:513-518

Silva MDM, Barajas-Aceves M, Araújo ASF, Araujo FF, Melo WJ (2014) Soil microbial biomass after three years of consecutive composted tannery sludge amendment. Pedosphere 24:469-475

Singh RP, Agrawal M (2008) Potential benefits and risks of land application of sewage sludge. Waste Manag 28:347-358

Singh RP, Agrawal M (2010) Effect of different sewage sludge applications on growth and yield of Vigna radiata L. field crop: metal uptake by plant. Ecol Eng 36:969-972

Singh RP, Singh P, Ibrahim MH, Hashim R (2011) Land application of sewage sludge: physico-chemical and microbial response. Rev Environ Contam Toxicol 214:41-61

Spedding TA, Hamel C, Mehuys GR, Madramootoo CA (2004) Soil microbial dynamics in maize-growing soil under different tillage and residue management systems. Soil Biol Biochem 36:499-512

Swisher R, Carroll GC (1980) Fluorescein diacetate hydrolysis as an estimator of microbial biomass on coniferous needle surfaces. Microb Ecol 6:217-226 
Taylor JP, Wilson B, Mills MS, Burns RG (2002) Comparison of microbial members and enzymatic activities in surface soils and subsoils using various techniques. Soil Biol Biochem 34:387-401

Tedesco MJ, Gianello C, Bissani CA (1995) Analises de solos, plantas e outros materiais. UFRGS, Porto Alegre, p 252
Whittinghill KA, Hobbie SE (2012) Effects of pH and calcium on soil organic matter dynamics in Alaskan tundra. Biogeochemistry 111:569-581

Yeomans JC, Bremner JM (1998) A rapid and precise method for routine determination of organic carbon in soil. Commun Soil Sci Plant Anal 19:467-1476 